\title{
MYSTERY OF CORONA VIRUS - A REVIEW
}

\author{
Dr. Satyesh Chandra Roy \\ Former Professor and Head, Department of Botany, Co-Ordinator, Centre of Advanced Study \\ Cell and Chromosome Research Centre, Emeritus Professor, Member of the Senate, \\ Calcutta University
}

\begin{abstract}
The global pandemic of Corona virus has made a panic in all places. This has raised questions to many to know the real origin of the present virus. Different views regarding its origin as natural or through some manipulation have been discussed to solve its mystery.
\end{abstract}

Key words; Corona virus, SARS-Cov-2, Covid 19, Bioweapon.

\section{INTRODUCTION}

The Corona virus outbreak has brought a greatest crisis throughout the world. More than 3.66 million confirmed cases and total death of $1.2 \mathrm{~m}$ has occurred worldwide till April 2020 making this disease a global panic. Italy, Iran, Spain, UK and United States are the worst hit countries in addition to China which was the first epicentre of the disease Covid 19. Sudden occurrence of such dreadful Corona Virus throughout the world causing Global Pandemic is still a mystery. Many views are coming to the mind of several people including Social Media regarding its origin and the person or country responsible for this global pandemic. It may be used as a Bioweapon by some country or it may be modified in the laboratory to hit the economy and progress of some nation or it may origin through natural mutation due to the destruction and alterations in Ecosystem and Biodiversity of the Earth by human being. Thus we have in our mind a proverb, "there is no smoke without fire ".

Biowarfare or Biological weapons may be virus, bacteria, fungi or toxins produced from biological organisms that are used for mass destruction to gain a strategic gain over the enemy or to affect the economy of developed countries. These biological agents have the potential to create more loss of life than any other conventional weapons including nuclear ones without declaring any war and at a minimum cost. In some cases, biological weapons are made through genetic engineering technique for creating novel dreadful weapons by inserting new genes in their genetic material in the most virulent viruses or bacteria.

\section{EARLY HISTORY OF USING MICROBES AS BIOWEAPON}

Biological weapons were used long ago as early as the $14^{\text {th }}$ century BC by Hittites. They established an empire on Hattusa which is now a part of Turkey,

Syria, Lebanon and Cyprus. Their empire was originally known as Anatolia having Asia Minor, Asia Turkey and large peninsula in West Asia (Barras et al 2014).

Both in $14^{\text {th }}$ century and $4^{\text {th }}$ century Hittites used rams infected with Tularaemia (one type of virus) against their enemies and infect their arrows by dipping into decomposing cadavers of Viper and human blood respectively as Bio weapons. Later Grmek found in 1979 that this mixture may contain fungi Clostridium perfringens and C. tetani as well as the Snake`s venom (GrMek 1979). It has also been found that biological weapons were used by different empires from the year 1155, 1346,1422, 1495, 1650, 1710, 1763, 1797and 1863 AD before the Microbiology era in Science. Following these events two international declarations were made in 1874 and 1899 at Brussels and The Hague to prohibit the use of poisonous weapons against any country.

After a long gap the German army used biological and chemical weapons for mass destruction in the First World War. After the war Sir Frederick Banting, Nobel Prize winner for the discovery of Insulin, first developed private Biological Weapon Research centre in North America in 1940. Then US Government along with British allies started the programme for developing biological weapons. Japan used Biological weapons against human and animal populations in Asia during 1932 to 1945 (Culpepper et al 2002).

In the last stage of World War II, Japan had a plan to use plague as a biological weapon against United States in California but the plan was finally not executed because of the surrender of Japan in the world war in 1945. UK started to make biological weapons in 1950 with plague, brucellosis, tularaemia, vaccinia viruses and others but the programme was finally cancelled in 1956. Soviet scientists developed many antibiotic resistant and 


\section{International Journal of Engineering Applied Sciences and Technology, 2020 Vol. 5, Issue 2, ISSN No. 2455-2143, Pages 413-418 \\ Published Online June 2020 in IJEAST (http://www.ijeast.com)}

vaccine subverting strains of smallpox, anthrax, tularaemia through genetic engineering techniques to use as bioweapons during 1980 and 1990. United States also developed biological warfare programmes taking ten or more agents including toxins to kill humans and to destroy crops or livestock. Then US President Richard Nixon banned production of Biological weapons to use in war but these can be produced for scientific research. The Biological and Toxin Weapons Convention was formed by US, UK, USSR and other countries and the resolution was taken to ban the development, production and stock-piling of microorganisms and their toxin products to use as warfare except for scientific research (Roffey et al2002, Frischknecht 2003). However, many countries have active biowarfare programmes in recent years which include Russia, Kazakistan, Syria, Iraq, Iran, Libya, North Korea, Israel, Egypt, Taiwan, China, South Africa, Cuba, Romania, Bulgaria, Pakistan, India, UK, France, Germany, Netherlands, Norway, Sweden, Canada and the United States (Leitenberg 2000). Several Terrorists organizations are also developing bioweapons through the application of different microbes including toxins.

Terrorists use these as their weapons as the cost of production is less than any other conventional weapons. There is another advantage for terrorists as they can escape easily before the start of the investigation to find out the terrorists (Barras et al 2014; Dudley et al 2002). In 2002, CNN found that Al-Qaeda`s terrorists group is beginning to plan attack with toxin Ricin and Cyanide to many countries. They are planning to attack in causing potential danger by injecting the deadly substance into the facility of any establishment. US Department of Agriculture have declared three categories of Biological Agents that have the potential to pose a serious threat to health and security. Three categories are i) those affect only humans; ii) those affect only animals or crops; and iii) those that overlap and affect both.

The important characteristics of a dreadful bioagents for targeting the human populations at continental and global levels should have the following criteria:

i) It has the potential to transmit easily from human to human causing high percentage of infected cases ;

ii) It will cause high mortality to affect public health of that country including the disruption of health-care facilities;

iii) It will cause panic among the population to cause social changes iv) It will require special methodology to eradicate the agents

It is interesting to note that all these categories are present in the Corona virus Sars-Cov-2 causing the global pandemic disease Covid 19 (Fischetti et al 2020).

Thus there is every possibility that the present Corona virus can be easily developed by any country for nefarious activities.

As the outbreak of the disease corona virus ( Covid (19) was first recognised in December 2019 in Wuhan city of China, so it was thought that the disease have transmitted from animal to human due to the presence of sea food and live animal markets in that city. Again they are eating the meat of wild animals and are also selling these meats in different countries ( Karindalam 2020).

From February onwards the disease becomes pandemic to about 187 countries of the world leading to the generation of idea that China may be the party to spread the disease intentionally or inadvertently. Again another view has also originated that the accumulation of all these specific virulent characteristics to a single organism is not possible without the help of long research in any sophisticated laboratory or in other words may be a laboratory construct. But it is still a mystery as it is not confirmed.

The conditions occurred throughout the world due to corona virus may be compared with that of World War. During World War II the scientific and medical expertise worked jointly to fight the war in most of the countries in Europe and United States. Similar condition is found to fight the covid-19 crisis in all countries of the world.

The mobilization of scientific and medical experts occurs in collaboration with the Government and industry in all countries to stop Covid-19 as their final goal on an emergency basis to find out a proper Vaccine. In this context, this global fight of Covid 19 can be called a World War III in 2020 without any attack of bombs or nuclear warfare but with a new weapon Bioagents.

\section{VIEW FOR MAKING NOVEL PATHOGENS IN THE LABORATORY AS BIOWEAPON}

The danger caused by these bioagents or viruses is called asymmetric threats meaning threats that attack us are sudden and unprepared and the perpetrator is unknown leading to an unprecedented global crisis. 


\section{International Journal of Engineering Applied Sciences and Technology, 2020 Vol. 5, Issue 2, ISSN No. 2455-2143, Pages 413-418 \\ Published Online June 2020 in IJEAST (http://www.ijeast.com)}

There are reasons to think that i) the present corona virus causing Covid 19 disease is a Chinese bioweapon that comes out deliberately or accidentally. Ii) Again the Wuhan Institute of Virology is located in the city of Wuhan and iii) there is also Wet market in the same city where wild animals are sold for meat. Iv) There is also an institute of Virology at Wuhan which has a Biosafety Level 4 laboratory where potentially dangerous biological agents like viruses and bacteria are isolated to use as Bioweapons (Prasannan 2020). Dr. Francis Boyle, the creator of Bioweapons Act, said that the Corona virus is an offensive biological warfare weapon with DNAgenetic engineering.

In the past history of World War II during 1939 45 , the mobilization of scientific research scientists and medical personnel led to the formation of the Office of Scientific Research and Development (OSRD) by President Roosevelt of US with fund of $\$ 500$ million to fight the war. This collaborative research came out with the success of many discoveries like mass production of first wonder drug an antibiotic - the Penicillin, atom bomb, modern method of computing, many new instruments, napalm bombs, new rockets and many more. With the help of these extra funds and support of Government and Industry many Universities and research institutes were benefited to develop America into a scientific and technological power house of the world. The tremendous development of United States in the post second world war period led to the success in every spheres of science, technology, industry, military power etc leading the world in getting maximum Nobel Prize of 375 till 2019 and also to become a BIG POWER of the world.

So there may be also a reason to halt the progress of United States by China using this dreadful virus.

Now I think there again comes an opportunity for developing countries to come forward to work united as one nation with a goal of achieving advancement in Science, Technology and Health Sector to become another Big Power in the world.

With the development of Genetics, Molecular Biology, Biotechnology and technological advancement there is a diverse opening in different aspects to use these knowledge and either for beneficial purposes or for nefarious applications. Again with the publication of the first complete genome sequence of the bacteria Haemophilus influenzae in 1995, more than 1000 genomes of different microbes including large number of viral genomes have been completed and further is in progress. Till now genome sequences of more than 90,000 influenza viruses were done and were deposited in Gene Bank for easy availability to the scientists and non scientists. All these data will help to understand the evolution of pathogens and will also help to know the reason for the emergence of new infectious agents. Sequencing of different strains of same pathogens has facilitated to understand the evolution and virulence of the virus in a better way and also to make accurate diagnostic tools for epidemiological studies. But an open access to the genome sequence data may lead to its misuse by some nations to develop very easily some new types of infectious agents of more virulent with new host specificity by altering the genes like mobile genetic elements or regulatory elements of pathogens in the laboratory to spread global pandemics.

So the open access to Genomic resources is a threat to the security of any country as the publicly available information can facilitate in the modification of virulent microbes as a Biowarfare.

It is also known that there are many virulence factors (Virulence puzzle) encoded in the genome of any pathogenic organisms. These factors can be easily assembled in one pathogen to make a dreadful bio agent from the available Genome sequence Data very easily by any sophisticated laboratory. But this modern technology has been developed for using the data on Genome sequence of the pathogen to follow the outbreak of diseases very quickly leading to the development of diagnostics and medicines or vaccines for the pathogen for human welfare.

In the present Corona virus, the properties of spike protein has been mutated to increase the efficiency of its attachment to human cell for enabling the faster spread of the disease to the population of any country which goes for using it as a bioweapon. The use of Genetic engineering technology to make bioweapon is not new as the former Soviet Union developed novel anthrax by introducing the alien gene into the bacteria Bacillus anthracis in their Bioweapons programme.

As the genome of Corona virus contains the genetic elements of HIV and germ of malaria in the genome of corona virus, so this cannot be natural. This is the opinion of a French Nobel Laureate Mr. Montagnier who got Nobel Prize on his work on HIV. He claimed that the virus of Covid-19 was the result during the formation of vaccine against HIV in Wuhan Laboratory of China (Report from The Week), but many scientists from different countries including France showed from their research data that the view of Nobel laureate is not true. Still the present view of laboratory made corona virus persists in the mind of several persons. It is not clear why conventional biological weapons like 


\section{International Journal of Engineering Applied Sciences and Technology, 2020 \\ Vol. 5, Issue 2, ISSN No. 2455-2143, Pages 413-418 \\ Published Online June 2020 in IJEAST (http://www.ijeast.com)}

Smallpox, Anthrax, Ebola, typhus and others are kept as frozen stocks in many countries including China, United States and Russia. From these stocks, microorganisms can be used by any country or terrorists for increasing the virulence of pathogen through genetic engineering technique to use as Bioweapon or there may be a chance of leakage of any virus from these stocks in any laboratory to cause pandemic. There is an unconfirmed report that a biologist in Pakistan and North Korea has changed the microbe in the laboratory using very recent CRISPR technology of Molecular Biology that mimics the transmissibility and lethality of smallpox.

Recently American lawyer Larry Klayman and his group filed a lawsuit against Chinese Government and the Director, Institute of Virology of Wuhan for designing the Corona Virus to kill mass population and also to downgrade the economy of other countries (Madhukalva 2020). They also said that Chinese doctors and researchers first raised their voice to outside China to alarm the people of other countries by mentioning that virulent novel corona virus was prepared in Wuhan. Immediately the Chinese Government took serious action against them. This is another strong point for Corona Virus as laboratory made by China.

\section{SECOND VIEW OF CORONA VIRUS CAME NEARER TO MAN THROUGH NATURAL PROCESS:}

The wide spread of the disease Covid 19 to every country in the world has supported another view that this virus may not be man-made or a biological weapon. But more and more research showed that bats are the natural reservoir of large number of varieties of Corona Viruses.

Bats are the only mammals that fly and they are most numerous after Rodents (Rat family) and they eat insects and fruits. Due to deforestation and urbanisation, Bats have to fly for longer distances for food and so they are coming closer to human habitats or to the Animal Farm House which is also near to the human locality (Forni et al 2017; Vidal 2020) When a bat sits on a tree to eat fruit or to an animal shed for insect, it leaves traces of its body fluids. When persons come in contact with such trees, fruits, animals or shed, they become victims of deadly viruses that might have left their residues in these places. It has been found that the transmission of virus occurs from Bats to Human through Civet Cats during SARS outbreak (2002) while in case of MERS outbreak (2003) it occurs through Camel from Bats (Forni et al 2017). It has been more or less established that the present virus of COVID 19 is also transmitted from Bats and there is a chance of transmission of virus from Bats through the intermediate host, possibly Pangolin, the ant eating mammals to humans (Cyranosky 2020, Vidal (2020). During study of epidemics of SARS-

CoV in 2002 and 2003, it has been established that the transmission of SARS-CoV- 2 to human takes place through markets of wild animals of Wuhan in China selling the meat of civet cats, rodents, dog, pangolins etc. and thus becoming the first epicentre of corona virus. This market is also known as Wet Market where the meats of Civet Cat, rodents, dog, Pangolins, Fox, Crocodile etc are sold in the market and is traded and trafficked for human consumption to other countries. So the corona virus uses these animals of the market as vectors for their transmission to human.

Different types of Bat corona viruses are studied in the Wuhan Institute of Virology and at the Centre for Disease Control and Prevention located 280 metres away from the Hunan Sea Food Market at the same city of Wuhan and so Professor Richard Ebright of Rutger`s University is of the opinion that there may be an accidental leakage from a laboratory to cause global pandemic of the disease. But Professor Thomas Gallagher of Loyola University of Chicago said that Sars-Cov-2 was originated in animals and not in the laboratory. The wide use of wild and domesticated animals as food for long time by human having insatiable desire to eat animals slowly changes the ecosystem of the virus. Again the crowding of many animals in a small space of Farm Houses makes it as amplifier for viral pandemics. Michael Gregor in his book 'BIRD FLU: VIRUS OF OUR OWN HATCHING' warns that factory farming is a perfect storm environment for infectious diseases (Roy 2020).

In December 30, 2019, the Wuhan Centre for Disease Control and prevention first detected novel corona virus patients in two hospitals and asked the virologist Shi Zhengli of the Wuhan Institute of Virology to investigate. It was thought that this virus is similar to the same family of viruses that caused the earlier disease SARS which infected 8100 people and killed about 800 between 2002 and 2003. Shi was also known as Bat woman of China by her colleagues as she made virus-hunting expeditions in large number of bat-caves for the last sixteen years and collected many strains of virus from caves for research purpose (Qiu 2020). The objective of her expeditions was to find out the culprit of the first epidemic by SARS corona virus. It was found that SARS virus was transmitted to human from Bats via civet cats (mongoose like mammals). 


\section{International Journal of Engineering Applied Sciences and Technology, 2020 \\ Vol. 5, Issue 2, ISSN No. 2455-2143, Pages 413-418 \\ Published Online June 2020 in IJEAST (http://www.ijeast.com)}

Before SARS outbreak, corona viruses were known for causing common colds. So the SARS outbreak was a game-changer with pandemic potential.

Shi and her team found that the presence of corona virus in Bats was ephemeral and seasonal through their long expeditions in different caves of China. They also found large number of bat-borne corona viruses with genetic diversity. They then cultured some viruses in the laboratory in a petridish and also found that they can infect human cells and may cause SARS like disease with respiratory syndrome when injected to mouse. It has been noted that constant mixing of different viruses may have opportunity to develop new dangerous pathogens by Ralph Baric, virologist of the University of North Carolina. Research groups of China found diverse group of corona viruses in six species of bat. Sometimes multiple strains of a single virus infected one animal causing it a factory for the synthesis of new novel virus. These observations indicate that pandemic like outbreak of corona virus may occur any time if the handling and use of wild life is not banned immediately. Then they started testing of patients for corona virus through Polymerase Chain Reaction Test and Antibody tests from the blood sample of patient in December 2019 to confirm that the genetic sequences of corona virus are present in the infected persons. Research team of Wuhan also found that the genomic sequence which is found in the patient is identical to the virus found in horse shoe bat of Yunnan and is named as SARS-Cov-2. Shi and her team reported that the genetic sequence of the present corona virus causing global pandemic does not match with any of the viruses present in her laboratory. But the doubt remains that the present Covid 19 virus might occur due to leakage from the laboratory, if not intentionally which again remains as a mystery.

Another chance of global spreading of corona virus may be due to the encroachment of wild life habitats due to deforestation with the unprecedented changes in land use by construction of roads, many high rise buildings or in other words, urbanisation for increasing growth of human population. Daszak and others studied about 500 infectious diseases to find out the reason for their spread as epidemic or pandemic. They also noted that the emergence of new pathogens occur in places where the human population is changing the Biodiversity of the planet by building roads and mines through deforestation, urbanisation and extension of agricultural land making the place as Hot spot for Pandemics. Thus the changes in the behaviour may occur through natural selection. But nothing is confirmed to solve the mystery.
The traditional Chinese medicine is used for various types of diseases like arthritis, epilepsy, erectile dysfunction etc. by using extracts of body parts of different animals tigers, bears, pangolins, rhinos and others. This also increases the animal human interactions causing changes in the ecosystem.

All these lead to a change in the normal circulation of viruses and shifting of the behaviour of viral reservoir species like bats and other animals. The behavioural changes of virus and carriers may lead to changes in transmission from human to human even without using any intermediate host (Roy 2020).

Research on China showed that the virus SARSCov-2 is a naturally occurring species as it is related to another Bat corona virus RaTG13. But when the comparative sequencing was done it was found that the sequence of receptor binding domain has similarity with that of Pangolin rather than virus RaTG13 as claimed by China. Thus the naturally occurring theory of China is no longer tenable. Again it remains in a mystery.

From the sequence data it has been found that the Pangolin sequence differs from COVID 19 virus by one amino acid only while RaTG13 virus of Pangolin differs in seventeen positions indicating the presence of new gene in the Pangolin. Again the Receptor binding domain in COVIS 19 is very critical to infect humans by binding to human Ace 2 (Angiotensin-converting enzyme 2) receptor showing thereby that the pangolin receptor binding domain might be introduced to COVID 19 virus through some recombinant process to enhance pathogenicity and transmissibility to humans in Corona virus (Sellin 2020)

Whatever it is, this new gene of ACE 2 Receptor binding in the virus of COVID- 19 has originated through a recombination process showing thereby that this new gene has been introduced in a laboratory. But it was not confirmed so it is a mystery again.

\section{CONCLUSION}

Several views regarding the source and origin of infection of corona virus have been discussed. But no definite conclusions can be drawn. So it is a mystery.

\section{ACKNOWLEDGEMENT}

The author would like to express his thanks of gratitude to his wife Chayna Roy for her constant inspiration for the completion of this article. 


\section{International Journal of Engineering Applied Sciences and Technology, 2020 \\ Vol. 5, Issue 2, ISSN No. 2455-2143, Pages 413-418 \\ Published Online June 2020 in IJEAST (http://www.ijeast.com)}

\section{REFERENCES}

1. Barras, V, Barras I, Greub, G ( 2014). History of biological warfare and bioterrorism. Clinical Microbiology and Infection . 20(6): 497-502.

2. Culpepper, T., Darling,R , Rowe, R. Mckee, J, Eitzen .K.jr.(2002).Medical Management of Biological Casualties Handbook, $4^{\text {th }}$ Edition , ed. By Detrick, F. MD. US Army Med. Res. Cited from Bioscience (2002) 52( 7) :583-592.

3. Roffey, R., Tegnell, A., Elgh, F. ( 2002) . Biological warfare in a historical perspective . Clinical Biol. Infect. $8: 450-454$.

4. Frischkencht , F. ( 2003 ). The history of biological warfare. EMBO Reports 4 (Special Issue ) : S $47-$ S 52 .

5. Dudley, J. P., Woodford, M. H. ( 2002 ). Bioweapons, Biodiversity and ERcocide Potential : Effects of Biological weapons on biological diversity. Bioscience . 52:593-595.

6. Fischetti , M.. Falconieri Hays, V., Glaunsinger , B ., Christiansen , (2020). A Visual Guide to the SARS- CoV -2 Coronavirus . Sci. Amer. July issue

7. Karindalam , A . ( 2020 ). Dread of the Corona Virus. The Week . 38 (6) : $36-37$.

8. Prasannan, R. ( 2020 ). Genie from a war lab . The Week . : 38 ( 6) : 47.

9. Cyranosky, D. B( 2020 ). The biggest mystery : what it will take to trace the corona virus source . Nature . 579 ( 7797 ) L 18 -19.

10. Madhukalva , A . ( 2020 ). \$20 trillion lawsuit against China ! US group says corona virus is bioweapon . Business Today, April 2, page missing

11. Forni ,D. , Cagliani ,R., Clerici ,M., Sironi, M. Molecular evolution of Human Coronavirus genomes . Trends in Microbiology .25(1) : 35- 48.

12. Vidal, J. (2020 ) . Destroyed Habitat creates the perfect conditions for corona virus to emerge. Sci. Amer. March 18 .

13 . Roy , S.C. ( 2020 ). Corona virus - origin . replication and remedy for future threat . Sci. \& Culture . 86 (5) : $137-143$.

14. Qiy , J. ( 2020) . How China`s " Bat Woman “ Hunted down viruses from SARS to the new coronavirus . Sci. Amer. 322: 20- 24.
15. Sellin , L. ( 2020 ). Explained : Scientific indications that show Covid- 19 is man- made . Sci. Amer. 322( issue 5) . page missing. 